\title{
Dogmatisk kritikk av ensidig suicidologi
}

\author{
Anmeldt av Kim Larsen
}

HENSIKTEN MED denne boken er som tittelen sier å rette et kritisk søkelys på dagens suicidologiske forskning, samt å fremme alternative tilnærminger som i sin tur kan danne grunnlag for mer hensiktsmessige selvmordsforebyggende tiltak. Felles for forfatterne er at de ser suicidologien som begrenset og innsnevret ved at man anvender en medisinsk/psykiatrisk modell som individualiserer og dekontekstualiserer selvmord, samtidig som epidemiologisk forskning bærer preg av avtakende grensenytte ved å identifisere de samme risikofaktorene for selvmord på populasjonsnivå gang etter gang. Den dominerende forskningen er drevet frem av stringente vitenskapelige krav basert på randomiserte kontrollerte studier og evidensbasert profesjonsutøvelse, noe som ifølge forfatterne bidrar til å fjerne forskningen både fra det opplevelsesnære og fenomenologiske på den ene siden, og fra den historiske, kulturelle og politiske kontekst et selvmord nødvendigvis forekommer i på den andre siden. Ifølge forfatterne reduserer suicidologien noe som er multidimensjonalt og opplevelsesnært til å bli fremstilt som endimensjonalt og abstrakt.
Boken er delt i tre deler. I del én, «Rethinking suicidology», elaboreres den nevnte kritikken av dagens suicidologi (kap. 1-2), hvor forfatterne viser begrensningene i våre rådende suicidologiske forståelsesformer og eksemplifiserer med studier av bestemte populasjoner: urbefolkning (kap. 3), ungdom (kap. 4), og kvinners opplevelse av depresion (kap. 5). I del to, «Insider perspectives», gis beskrivelser av opplevelsen av suicidalitet «innenfra», fra den suici-

\section{Ifolge forfatterne redu-} serer suicidologien noe som er multidimensjonalt og opplevelsesnært til å bli fremstilt som endimensjonalt og abstrakt

dale selv. Det blir videre vektlagt hvordan den rådende suicidologiske forståelsen kan føre til uheldige møter mellom den suicidale og hielpeapparatet og hvordan dette $\mathrm{i}$ verste fall kan føre til en forverring av suicidaliteten. I del tre, «Creating alternatives: Reenvisioning suicide research and prevention», gir forfatterne eksempler på at det å benytte alternative tilnærminger skal kunne gi en bedre og mer utvidet forståelse og derved resultere i mer hensiktsmessige selvmordsforebyggende tiltak. Denne delen tar for seg seksuelle minoriteter («queer youth») (kap. 10), bruk av dikt og diktanalyse for å beskrive etterlattes fenomenologiske verden (kap. 11), beskrivelse av et lokalforankret selvmordsforebyggende tiltak i en urbefolkning i Kanada (kap. 12), og en analyse av vanlige grunnforutsetninger i selvmordsforebyggende skoleprogrammer (kap. 13). Redaktørene understreker i innledningen at kapitlene har en stor spennvidde og at dette er et onsket resultat; pluralisme og kreativitet fremfor ensretting og evidensbasert dominans.

Boken begynner svært lovende med en sofistikert kritikk av status quo i suicidologien ved henholdsvis Ian Marsh og Heidi Hjelmeland (kap. 1 og 2). Ian Marsh er tidligere kjent for sin glimrende bok Suicide: Foucault, history, and truth (2010) som er en nyansert og tankevekkende analyse av suicidologiens grunnforutsetninger og hvordan disse har endret seg opp giennom historien. Kapittel 1 er en kortversjon av denne boken. I kapittel 2 gir Heidi Hjelmeland kritikken om 


\section{CRITICAL SUICIDOLOGY}

Transforming

Suicide Research and Prevention for

the 21st Century

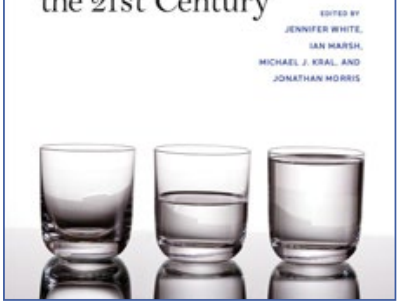

JENNIFER WHITE, IAN MARSH,

MICHAEL J. KRAL \& JONATHAN MORRIS (RED.)

Critical suicidology. Transforming suicide research and prevention for the $21^{\text {st }}$ century.

Vancouver: UBC Press. 2016.

ISBN: 978-0-7748-3030-0

(paperback)

metodologisk ensidighet i suicidologien et kvantitativt uttrykk ved å studere hvilke metoder som er benyttet i forskningsartikler i tre toneangivende internasionale tidsskrifter i årene 2011 og 2012. Denne giennomgangen viser dessverre en frapperende skjevhet; i disse to årene var kvalitative metoder eller en kombinasjon av kvalitative og kvantitative metoder anvendt i kun 5 prosent av artiklene i Archives of Suicide Research, mens det tilsvarende tallet for Crisis var 11 prosent. Hielmeland referer også Thomas Joiner, redaktør av Suicide and Life-Threatening Behavior, som fremstår til de grader ensidig i sin preferanse for kvantitative studier. I dette kapittelet presenterer forfatteren også en kritikk av eksisterende metoder (f.eks. psykologiske autopsier), og hun presenterer også konstruktive forslag til hvordan relevansen og kvaliteten på suicidologisk forskning kan heves ved bruk av en kombinasjon av kvantitative og kvalitative metoder (såkalte mixed designs).

Etter en lovende start med kapittel 1 og 2 ser jeg intenst frem til fortsettelsen. Her blir jeg imidlertid fort klar over ujevnheten i kvalitet mellom kapitlene. Spennvidden i temavalg er for så vidt forfriskende, men på tvers av disse viser det seg at alle forfatterne er nødt til å repetere den samme kritikken av tidsånden i suicidologien. Dette resulterer etter hvert i en litt gnagsåraktig leseropplevelse, som minner litt om den parodiske effekten Cato den eldre hadde i det Romerske senatet med sin eksessive repetision av sitt forslag om at Karthago burde ødelegges. Jeg tenker imidlertid at siden denne kritikken ikke så ofte kommer til orde i faglitteraturen, kan en bære over med litt understrekende gientakelser, og ser frem mot den mer praktiske delen av boken hvor vi vil få konkrete eksempler på alternative tilnærminger og deres praktiske nytteverdi. Men dessverre; jeg synes heller ikke denne delen av boken lever opp til forventningene. De konkrete alternative tiltakene er beskrevet på en ganske vag og rudimentær måte, og jeg synes giennomgående at forfatterne heller ikke klarer å argumentere overbevisende for hensiktsmessigheten av dem. Fremstillingen blir bare mer og mer outrert utover i boken; dels utarter prosjektene til å bli ren politisk aktivisme i stedet for forskning, dels bærer noe av fremstillingen preg nærmest av å være den medisinske modellen «i revers»; en slags invers version av det som kritiseres. Derved blir de også like ensidige. La oss ta noen eksempler som viser dette:

Suicide is not something that happens to one person, and it is not something that one person does. Nobody simply kills themselves. Events occur in context ... (s. 170)

Our children are born perfect: what is wrong is that we create structures of what is «normal». (s. 171)

They did not kill themselves; I believe their lives were stolen. (s. 172)

... social injustice, hate, stigma, and oppression create the conditions that make the horror of suicide possible. (s. 184)

I noen tilfeller synes også fremstillingen å bekrefte stråmannspregede fordommer mot kvalitativ forskning. Hva med dette: «We do not wish to saturate such nuanced and beautiful stories [om etterlattes opplevelse av selvmord] with our own analysis. We are elevating insider knowledges.» (s. 127). Greit nok det, men da er dette vel knapt nok journalisme og i hvert fall ikke forskning. Det er jo også ganske 
uvant å finne noen som ikke vil analysere sine data i en bok om vitenskap.

Det finnes imidlertid også gode og tankevekkende analyser inniblant. Særlig synes jeg analysene av potensielt uheldige effekter ved tradisjonelle selvmordsforebyggende skoleprogrammer (kap. 4 og 13) samt beskrivelsen og tolkningen av opplevelsen hos etterlatte ved hielp av poesi (kap. 11), er eksempler på dette.

Mitt utgangspunkt for å lese denne boken er at jeg har det samme synspunkt som forfatterne; mye suicidologisk forskning preges av avtakende grensenytte, det utføres for lite kvalitativ forskning, en åpenbar måte å rette opp dette på er utstrakt bruk av en kombinasjon av kvantitative og kvalitative metoder. Når det gielder selvmord, tenker jeg at det er avgiørende å gripe nettopp det fenomenologiske og psykologiske, noe som gir kvalitative metoder et privilegert potensiale. Derfor er det så synd at Critical suicidology. Transforming suicide research and prevention for the 21st century karakteriseres av de samme ensidigheter som bokens forfattere anklager hos mainstreamsuicidologien. Dette kan dessverre resultere i en unødvendig polarise- ring i faget. I en klassisk monografi fra 1959 beskrev C.P. Snow, som selv var både kjemiker og skjønnlitterær forfatter, hvordan den vestlige kultur erkjennelsesmessig var preget av et grunnleggende skisma mellom naturvitenskapen og humaniora. Han kalte disse for «de to kulturer», og beskrev hvordan de eksisterer som to separate erkjennelsesmodi side om side uten å interagere eller overlappe. Naturvitenskapen karakteriseres av positivisme, mekanistisk tenkning og universalisme, mens humaniora karakteriseres av hermeneutikk, konstruktivisme og relativisme. I stedet for å bidra til å opprettholde dette skismaet, la oss giøre som Heidi Hjelmeland foreslår i kapittel 2: å begrunne metodevalgene i fenomenet vi skal studere og hvilke metoder som best kan belyse dets multifasetterte kompleksitet. Det bør være avgiørende, ikke en sementert teoretisk forforståelse. Det første er forskning, det andre er dogmatikk. La oss bruke vår energi på å utfylle hverandre vitenskapelig og ikke føre skyttergravskriger.

Boken har et svært avgiørende budskap, men dette skjemmes dessverre av en polemisk og dogmatisk form. For å skape større forståelse og aksept for sine argumenter, som jeg som nevnt har stor forståelse og sympati for, ville forfatterne tient på å legge mindre vekt på kritikk av den dominerende kvantitative forskningen i suicidologien og mer vekt på å vise i praksis hvilke fortrinn gode kvalitative studier kan ha.

\section{REFERANSER}

Marsh, I. (2010). Suicide: Foucault, history and truth. Cambridge: Cambridge University Press.

Snow, C.P. (1959). The two cultures and the scientific revolution. Cambridge: Cambridge University Press. Norsk oversettelse: De to kulturer. Med et innledende essay av Vidar Enebakk. Oslo: Bokklubbens kulturbibliotek. 2008. 